\title{
Sediment, glaciohydraulic supercooling, and fast glacier flow
}

\author{
Richard B. Alley, Daniel E. LAWSON, ${ }^{2}$ Edward B. EVEnSON, ${ }^{3}$ Grahame J. LARSON ${ }^{4}$ \\ ${ }^{1}$ EMS Environment Institute and Department of Geosciences, The Pennsylvania State University, University Park, PA 16802-7501, U.S.A. \\ E-mail: ralley@essc.psu.edu \\ ${ }^{2}$ U.S. Army Cold Regions Research and Engineering Laboratory, 72 Lyme Road, Hanover, NH 03755-1290, U.S.A. \\ ${ }^{3}$ Department of Earth and Environmental Sciences, Lehigh University, Bethlehem, PA 18015, U.S.A. \\ ${ }^{4}$ Department of Geological Sciences, Michigan State University, East Lansing, MI 48824, U.S.A.
}

\begin{abstract}
Glaciers often advance over proglacial sediments, which then may enhance basal motion. For glaciers with abundant meltwater, thermodynamic considerations indicate that the sediment-ice contact in the direction of ice flow tends toward an angle opposed to and somewhat steeper than the surface slope (by slightly more than $50 \%$ ). A simple model based on this hypothesis yields the extent of over-ridden sediments as a function of sediment thickness and strength, a result that may be useful in guiding additional fieldwork for hypothesis testing. Sediment-floored as well as rock-floored overdeepenings are common features along glacier flow paths and are expected based on theories of glacier erosion, entrainment, transport and deposition.
\end{abstract}

\section{INTRODUGTION}

Fast glacier flow is favored by subglacial sediment, which can bury bedrock roughness to increase sliding (Weertman, 1964), deform to increase ice velocity (e.g. Blankenship and others, 1987; Alley and others, 1989; Clark and others, 1999; Tulaczyk and others, 2000; Boulton and others, 2001) and constrict basal channels to raise basal water pressure, speeding sliding and deformation (Alley, 1989; Walder and Fowler, 1994). Subglacial bedrock erosion usually is not expected to produce thick, continuous till sheets (Cuffey and Alley, 1996; Alley and others, 1997; cf. Tulaczyk and others, 2001); thus, over-riding of proglacial sediments is important.

Here, we hypothesize that beneath glaciers with abundant meltwater flow, the slope of the up-glacier side of over-ridden sediments evolves towards an angle controlled by the thermodynamics of the system and the strength of the sediments. We show that this hypothesis is consistent with available data on glacial sedimentary processes, and leads to a simple model that can be used to guide additional hypothesis tests. If this hypothesis is correct, soft subglacial sediments will be extensive owing to the shallow angle taken by their up-glacier sides.

\section{PROGLAGIAL SEDIMENT AGGUMULATIONS}

Several processes combine to cause advancing glaciers to encounter thick proglacial sediment accumulations. We begin with a brief review of these processes; workers familiar with the glacial sedimentary system may wish to skip this section and the next one.

Reported glacial erosion rates range from essentially zero to probably the fastest sustained values observed for any erosive processes on Earth (e.g. Hallet and others, 1996). Erosion of subfreezing beds (Cuffey and others, 1999) or thawed beds beneath cold ice typically is slow, but the onset of surface meltwater drainage to the bed greatly increases the number and vigor of subglacial erosive processes (e.g. Lawson, 1986;
Iverson, 1991; Hallet, 1996; Alley and others, 1997). Despite millions or tens of millions of years of erosion, the meltwater-poor Antarctic ice sheet still rests on upper-crustal rocks in many places (e.g. ten Brink and others, 1997), indicating orders-of-magnitude slower erosion than for, say, Alaskan tidewater glaciers with their abundant meltwater (Hallet and others, 1996).

Valley glaciers and many outlet glaciers characteristically deepen valley bottoms below levels that would have been produced fluvially, giving longitudinal profiles that are less steep and side-walls that are steeper than for fluvial systems (e.g. Brocklehurst and Whipple, 2002), as shown by, for example, Norwegian fjords, Yosemite Valley, California, U.S.A., and the Laurentian Great Lakes (Larson and Schaetzl, 2001). Some workers may call any such valley "overdeepened"; however, here we restrict the term "overdeepening" to a glacier bed depression in which the elevation of the down-glacier side (the "adverse slope") increases in the direction of ice flow. We include among overdeepenings those depressions closed by the up-glacier sides of morainal banks or shoals of tidewater glaciers.

For those glaciers with drainage of surface meltwater to the bed, Hooke (1991; also see Alley and others, 1999) argued that overdeepenings are favored by the processes of bedrock erosion. As reviewed below, even faster subglacial erosion of sediments also favors overdeepenings. We surmise that overdeepenings are not so much "accidents" as "steady-state" features toward which the glacial landscape evolves.

Glacial production of steep-walled valleys with nearly flat to overdeepened floors has numerous well-known implications for the glacial and glacial-geomorphic systems. In steep mountains with bedrock subject to landslides, the hypothesis of perfectly plastic hill-slopes (Burbank and others, 1996) implies that any downwasting or retreat of glacier ice in excess of sediment replacement will tend to destabilize oversteepened slopes. The resulting landslides can extend upslope to reduce the elevations of ridge-lines and peaks (Meigs and 
Sauber, 2000), producing large sediment fluxes (e.g. Warren and Kirkbride, 1998; Meigs and Sauber, 2000). Glacial retreat may lower base level for streams entering a deglaciated valley, releasing more sediment into the proglacial environment (Meigs and Sauber, 2000; personal communication from A. Meigs, 2002). Such behavior may contribute to the observation of Hallet and others (1996) that recent sediment yields from mountain glaciers often have exceeded longer-term averages (which themselves are higher than for equivalent fluvial systems) (cf. Meigs and Sauber, 2000; Koppes and Hallet, 2002). This implies that sediment fluxes may be higher during glacial retreat than during advance.

The reduced or reversed long-profile slopes of deglaciated valleys often serve as sediment traps, reducing sediment flux to regions farther downstream (e.g. Carter and others, 2000) at times when sediment production may be especially fast upstream of the traps. Resulting sediment accumulations in front of retreating glaciers can reach hundreds of meters or more in thickness (e.g. Barnes, 1987; Nolan and others, 1995; Björnsson, 1996; Warren and Kirkbride, 1998). Sediment may accumulate on newly established fluvial surfaces, and may be finer-grained and thus better at lubricating subsequent glacier advances if accumulation is in fjords following marine incursion or in lakes formed in overdeepenings. Isolation of ice in an overdeepening by downwasting or backstepping of active flow, followed by sediment burial slowing ablation (e.g. Chinn, 1996), migration of the locus of proglacial-stream activity, and subsequent formation of a kettle lake, may contribute to trapping of finer-grained sediment.

Glaciers have rather limited ability to push material in front of them, based on models and observations (e.g. Mickelson and others, 1983; Bennett, 2001). A stress concentration in ice from interaction with an obstacle occurs over distances comparable to the obstacle size (e.g. Weertman, 1964; Kamb and Echelmeyer, 1986), so a sediment pile larger than a few tens of meters with typical sediment strength of tenths of a bar would cause the ice stress to exceed the few-bar level at which rapid yielding or failure occurs. Somewhat more extensive pushing may be possible if sediment occurs in thin sheets or overlies a very weak décollement. A range of pushmoraine types is reported in the literature (e.g. Bennett, 2001), with many mechanisms of formation (and some disagreement on those mechanisms), but ice-pushing sufficient to keep many natural proglacial sediment accumulations in front of a glacier is not expected (e.g. Mickelson and others, 1983; Bennett, 2001).

Barring certain eventualities (such as formation of highly competent ice-marginal streams), the inability of glaciers to bulldoze large quantities of sediment means that advancing glaciers initially over-ride proglacial materials (e.g. Mickelson and others, 1983; Nolan and others, 1995). Over-riding enables subglacial transport processes (subglacial streams, deforming glacier beds, and entrainment of sediment into the ice; reviewed by Alley and others, 1997), excavating sediment rapidly. Sediment from subglacial streams and deforming beds is delivered back to the proglacial environment (Lawson, 1979), and debris and meltwater from accreted basal ice form hummocky morainal complexes (Lawson, 1979).

This recycling of sediment in front of glaciers can lead to very large sediment fluxes; for example, Powell (1990) reported local sedimentation rates of $30 \mathrm{ma}^{-1}$ at Riggs Glacier, Alaska, U.S.A. This in turn can lead to filling of lakes or fjords, aggradation of proglacial streams, and an increasingly thick sediment package into which the ice advances.

\section{SUPERCOOLING GONTROLS ON MORAINE SLOPES}

In previous works (Alley, 1997; Alley and others, 1999) we suggested that supercooling of rising subglacial waters provides an important control on recycling of the over-ridden sediment. Here we develop this idea further.

Many glaciers experience rapid surface melting, and channel the water to their beds and along the beds to the ice front (e.g. Röthlisberger and Lang, 1987; Paterson, 1994). Typically, basal water flow is driven primarily by the potential gradient arising from the ice-surface slope, from higherpressure regions beneath the ice to lower-pressure zones at the ice front. (Equations are summarized by Alley and others (1998).) Close contact with ice maintains the flowing water near the pressure-melting temperature, which increases with decreasing pressure by approximately $0.001^{\circ} \mathrm{C}$ per $m$ reduction in ice thickness. The water flow is nearly non-accelerating, so the work done is dissipated as heat. In many situations, this heat is sufficient to warm the water along the pressure-melting curve and to cause additional melting of adjacent ice; however, when basal water flows up the sufficiently steep adverse slope of an overdeepening, the increase in the potential energy from elevation reduces the heat generation below that needed to maintain the water on the phase boundary. Then, if other heat sources (e.g. geothermal heat) are small, the water will supercool and grow ice (Lawson and others, 1998), with the latent heat of freezing warming the water along the pressure-melting curve.

Calculations based on these principles (Röthlisberger and Lang, 1987; Hooke, 1991; Alley and others, 1998) show that if bed slope and surface slope have opposite signs, water flow will still be directed toward the ice front provided the magnitude of the bed slope is less than about 11 times that of the surface slope (depending in detail on the densities of water and ice). Supercooling is possible if the magnitude of the adverse bed slope is more than about 1.2-1.7 times that of the surface slope; a range is quoted because of uncertainty about the degree to which gas exchange between water and some unspecified reservoir will affect the air saturation of the water and thus the pressure dependence of the melting temperature. For the large water fluxes typical of temperate glaciers, the geothermal and sliding heats usually will be sufficiently small to allow supercooling and freeze-on to occur over appropriate bed slopes, assuming the water remains in intimate contact with ice and so does not reach the lowest points of overdeepenings at a temperature much warmer than the local pressure-melting temperature (Alley and others, 1998).

Data from Matanuska Glacier, Alaska, and from other glaciers (e.g. Lawson and others, 1998; Evenson and others, 1999; Roberts and others, 2002) show that supercooling does occur beneath glaciers having sufficient drainage of meltwater along a sufficiently steep overdeepening, and that this supercooling causes accretion of debris-rich basal ice. Much evidence additionally shows that this ice growth can largely or completely plug subglacial channels (e.g. Hooke and Pohjola, 1994). At Matanuska Glacier, marginal exposures reveal examples of water channels partially or completely plugged by ice that grew into them (Evenson and others, 1999).

On Matanuska Glacier, dye added to a large surface stream entering a moulin emerged from a vigorous vent feeding a proglacial river, but traveled at a rate consistent with 
flow through a water system with openings averaging just over $10 \mathrm{~mm}$ in diameter (Lawson and others, 1998). Turbid water discharging from vigorous vents in contact with sediment along the base of Matanuska Glacier almost completely lacks bed load although carrying abundant silt (Pearce and others, 2003), consistent with ice having plugged subglacial streams and greatly reduced their competence. Sediment may creep into and affect subglacial drainages as discussed by Walder and Fowler (1994), but is not modeled to reduce either bed load or water-flow velocities to the very low values observed for Matanuska Glacier. Subglacial streams also may be closed if ice flow carries them sufficiently rapidly against obstacles in the bed (Walder, 1982); however, the softsediment bed of Matanuska Glacier (Lawson and others, $1998)$ and the unremarkable velocity of the glacier $(\approx 0.2$ $\mathrm{m} \mathrm{d}^{-1}$ surface velocity across one overdeepening; Ensminger and others, 1999) argue against flow-pinching of channels being important there. Thus, subglacial water channels of Matanuska Glacier probably have been plugged by ice growth.

\section{OVERDEEPENINGS IN SEDIMENT: HYPOTHESIS}

An overdeepening can exist whether the adverse slope is bedrock, unconsolidated sediment or both. Drainage of water through subglacial sediments, or in low-gradient channels incised into moraine shoals, would reduce or eliminate supercooling; however, the common observation of turbid water discharging near tidewater-glacier calving fronts, and of streams exiting at the base of ice ending on land, indicates that significant basal water often does flow along, rather than through, glacier beds, aided by the tendency for glaciers to produce low-permeability subglacial diamictons.

Basal sediment transport can occur in basal ice or under the ice in meltwater streams or deforming beds. As reviewed by Hunter and others (1996a, b) and Alley and others (1997), most of the transport beneath tidewater and terrestrial glaciers with abundant drainage of surface meltwater to subglacial channels will be in those channels even over rather soft tills (Walder and Fowler, 1994), unless those channels are clogged by ice growth. The importance of stream transport is indicated, for example, by the commonly quite large sediment fluxes from many glaciers in comparison to the volume of their moraines (e.g. Bell and Laine, 1985; Lawson, 1993) (although basal ice produced from accretion of subglacial water has sufficiently high debris concentrations to produce large ice-marginal moraines; Lawson, 1979; Lawson and others, 1998).

Owing to the approximately cubic increase of sediment transport with water flux in a conduit (e.g. Alley and others, 1997), a distributed subglacial water system has only a small fraction of the sediment-transport capacity of a channelized system carrying the same total water flux. Any development of supercooling that plugs channels thus will greatly reduce the sediment flux. Even with Walder and Fowler (1994) canals in which water pressure increases with water flux, ice growth from supercooling will tend to plug regions of preferred water flow, thus spreading the water flow and reducing its ability to erode and transport sediments.

We therefore expect that a too-steep adverse slope of an overdeepening will become a sediment trap, capturing material delivered by streams from up-glacier as those streams lose their ability to transport that sediment owing to ice plugging the channels. (Trapping will preferentially affect coarser clasts because sufficiently fine material can be carried in the distributed water flow, with interesting implications for sorting of subglacial sediments (Pearce and others, 2003).) Such sedimentation in an overdeepening should decrease the magnitude of the adverse slope until supercooling is reduced enough that sediment continuity can be maintained in streams. The alternative, that till deformation, basal freezeon or other processes will remove sediment supplied by streams and thus allow an adverse slope that maintains a large amount of supercooling, is possible, but the very large sediment fluxes in some subglacial streams suggest that nonstream sediment removal will not be sufficient (e.g. Hunter and others, 1996a, b; Alley and others, 1997).

The highly variable sediment load observed at different times for a given stage in many proglacial streams (e.g. Lawson, 1993) shows that subglacial streams often have unfilled sediment-transport capacity. We expect that subglacial streams of a bedrock-bedded glacier overrunning a sediment deposit with a sufficiently gradual slope so that supercooling is not approached will tend to erode that sediment deposit to fill this transport capacity, starting with the sediment first encountered by the streams on the up-glacier side of the deposit. This in turn would lead to steepening of the up-glacier side of the remaining deposit.

Steepening may be favored further by any subglacial till deformation (e.g. Tulaczyk and others, 2001). Where sediment occurs in discontinuous patches on bedrock, flux by subglacial deformation will be less than in an equivalent situation with continuous sediment. If subglacial deformation occurs and there is a down-glacier transition from a glacier bed with exposed bedrock to one completely covered by unconsolidated sediment, the down-glacier increase in sediment flux will cause sediment loss near the bedrock-tosediment transition.

Thus, data and theory indicate that glaciers commonly advance into and overrun proglacial sediments and then recycle them. We hypothesize that where abundant surface meltwater is present and reaches the bed, the up-glacier sides of the overrun sediments tend to that angle (slightly more than $\sim 1.5$ times steeper than and opposed to the surface slope) capable of causing some supercooling of subglacial waters, reducing sediment transport somewhat to balance the enhanced sediment flux from till deformation and freeze-on accretion of the overrun sediments.

\section{OVERDEEPENINGS IN SEDIMENT: HYPOTHESIS TEST}

Available data support the importance of glaciohydraulic supercooling controlling the up-glacier slope of over-ridden sediment. Several modern glaciers (Lawson and others, 1998; Evenson and others, 1999; Roberts and others, 2002; Spedding and Evans, 2002) have shown supercooling of subglacial water emerging from overdeepenings. Sediment floors are likely for some of these, and known for Matanuska Glacier (Arcone and others, 1995; Lawson and others, 1998) and Kvíarjökull, Iceland (Spedding and Evans, 2002). At Matanuska Glacier, the occurrence of a sediment-floored overdeepening with basal-ice accretion (Lawson and others, 1998), exposures showing conduits plugged by accreted ice (Evenson and others, 1999), dyetrace evidence of distributed drainage (Lawson and others, 1998), and lack of bed load in basal discharge (Pearce and 

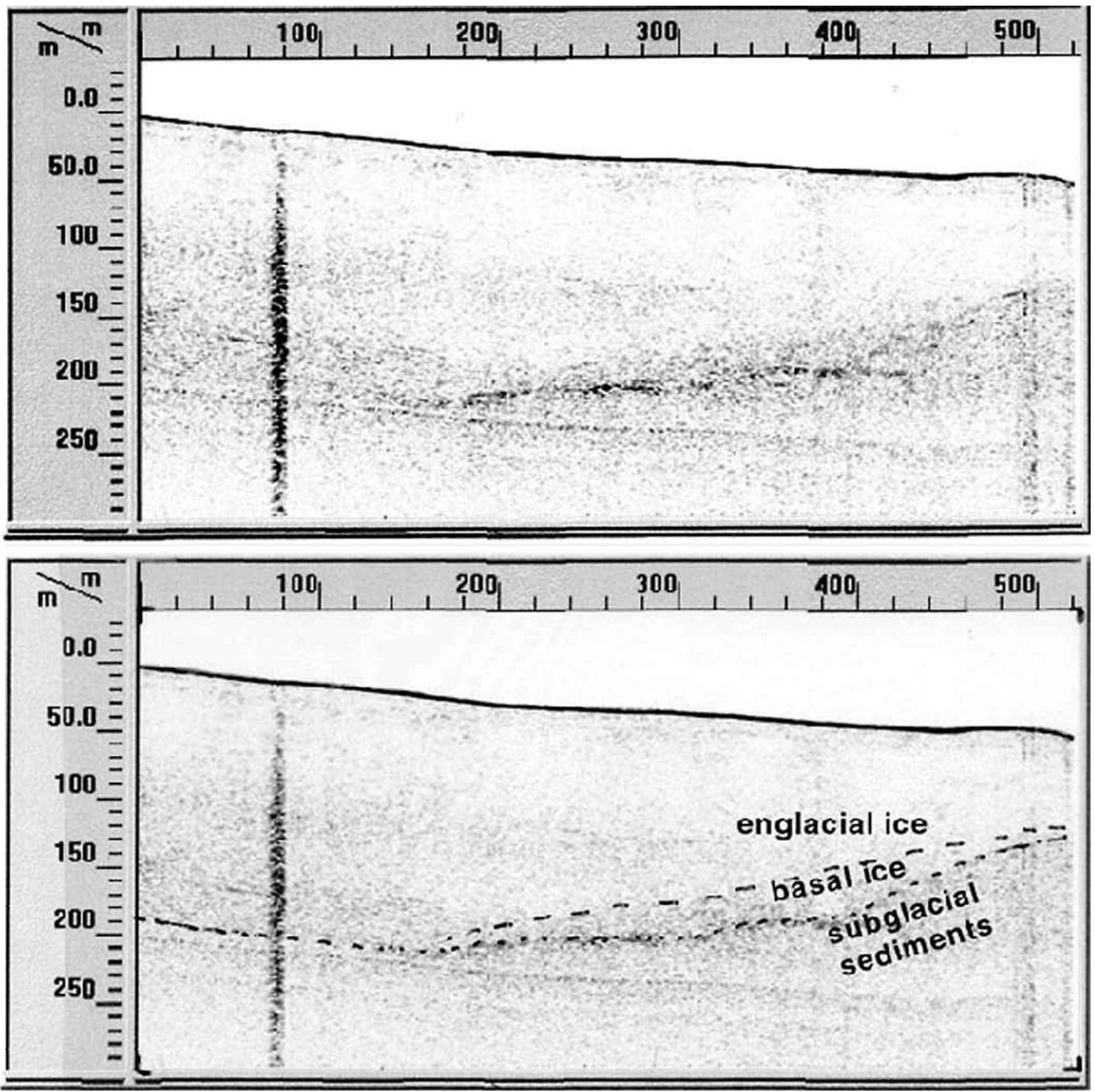

Fig. 1. Data and interpreted ground-penetrating radar profile of the lower $500 \mathrm{~m}$ of Muir Glacier, obtained approximately parallel to ice flow, left to right, in 1996. Interpreted contacts are shown between englacial ice and debris-rich basal ice, and between basal ice and subglacial sediment. The basal slope is steep enough relative to the surface to cause supercooling of water flowing along the ice-sediment interface. Modified from Arcone and others (2000).

others, 2003) provide much support for the hypothesis, although we as yet lack evidence for time evolution of the sediment slope in the overdeepening.

Muir Glacier, Alaska, experienced a rapid retreat, then stabilized and built a moraine shoal above sea level, primarily from subglacial fluvial discharge forming a fan delta along much of the ice margin. Recent data show that the up-glacier slope of this shoal is about twice as steep as the ice-air surface slope (Fig. 1); this basal slope is sufficient to cause considerable supercooling (cf. Arcone and others, 2000). During the time the terminus was becoming terrestrial, turbid water frequently was observed emerging on the surface of the glacier, forming debris-laden ice around vents after short-lived water discharge, with vent sites shifting rapidly over time. In addition, overthrusting of ice above the moraine shoal's up-glacier side was accompanied by water carrying gravelly sands being forced along thrust planes, indicating the presence of high basal-water pressures. This behavior is fully consistent with our understanding of the effects of supercooling plugging subglacial low-pressure channels to create high-pressure water capable of emerging on the surface (Hooke and Pohjola, 1994), and with supercooling during the upward flow of that water creating the debris-laden ice that grew in vents (Evenson and others, 1999; Ensminger and others, 2001).

A similar high-pressure basal water system in a region likely experiencing supercooling was observed at Columbia Glacier, Alaska. Before its catastrophic retreat, Columbia Glacier terminated on a steep moraine shoal of its own deposits (Meier and Post, 1987). Boring into the terminal overdeepening then (Humphrey and others, 1993) allowed turbid 


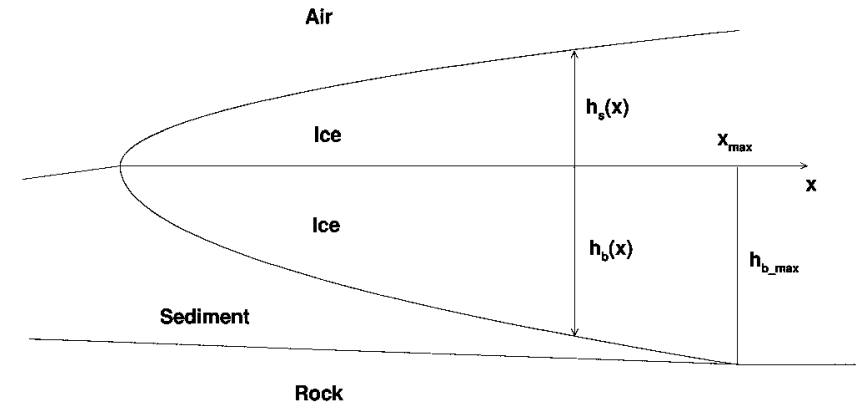

Fig. 2. Geometry used in perfect-plasticity model of subglacial sediment.

water to rise $180 \mathrm{~m}$ from the bed along the borehole and exit to the side into an englacial drainage system. Had this water continued along the bed to the ice front, the slopes would have caused supercooling, whereas the most direct englacial path from the point where the water exited the borehole to the ice front would not have involved supercooling (Humphrey and others, 1993). Such a basal water system operating at higher potential than an englacial system is consistent with closure of low-pressure basal channels by ice growth (Hooke and Pohjola, 1994). (Note that the observations of upwelling water were maintained for less than 2 days, perhaps not long enough to allow supercooling in the upwelling water to plug the borehole. Note also that closure of low-pressure channels is not uniquely a sign of supercooling, but might arise by ice flow carrying basal conduits against bedrock obstacles (Walder, 1982) or by creep of soft sediments into channels (Alley, 1989; Walder and Fowler, 1994), as noted above.)

Taku Glacier, Alaska, overrode proglacial sediments initially with a low surface slope, and then eroded them at rates of meters per year while building a moraine shoal above sea level (Nolan and others, 1995). Data from Nolan and others (1995, fig. 3 assuming nadir reflections) indicate an average slope of over-ridden sediments of about -1.4 times the surface slope in the reach $400-1600 \mathrm{~m}$ from the terminus. This approximates the supercooling criterion $(-1.2$ to -1.7 times the surface slope); slope fluctuations along the flowline fall above as well as below the supercooling criterion. Consistent with this, the glacier exhibits about $2 \mathrm{~m}$ of basal ice, with characteristics similar to those of basal ice grown from supercooled water at Matanuska Glacier (personal communication from R. Motyka, 2002).

We still do not have full documentation of glaciers overriding both too-steep and too-flat proglacial sediments, causing interactions between subglacial fluvial transport and supercooling that produce slopes causing some supercooling. Collecting such data is likely to be difficult, and is made more so by scarcity of advancing glaciers today, by loss of numerous overdeepened glaciers during retreat from Ice Age and Little Ice Age maxima, and by non-steady effects associated with recent retreat. Nonetheless, agreement of physical insight with available data from Matanuska, Muir, Taku, Columbia and other glaciers supports our hypothesis that subglacial sediment slopes with abundant meltwater fluxes do tend to that angle causing some supercooling.

We next develop this hypothesis further using a simple perfect-plasticity model (cf. Nye, 1951) to aid in additional hypothesis testing. This is a steady-state model. Taku Glacier eroded over-ridden sediments by meters per year (Nolan and others, 1995), indicating an adjustment time on the order of 100 years for hundreds of meters of sediment. It is likely that for many glaciers, post-Little Ice Age adjustment is approaching, but has not reached, steady state; thus, a steady-state model may be instructive, but non-steady modeling would be useful in the future.

\section{PERFEGT-PLASTICITY MODEL OF OVER- RIDDEN SEDIMENTS}

Much work (e.g. Tulaczyk and others, 2000) indicates that a Coulomb-plastic model is appropriate for subglacial sediment deformation. Regardless of the dominant processes controlling sediment flux, if subglacial sediment is continuous or nearly so and can be characterized by a yield strength, then the flow and form of the glacier will be influenced by that yield strength.

Assume that a glacier is over-riding sediment of uniform thickness $h_{\mathrm{b} \_ \text {max }}$ having plastic yield strength $\tau_{\mathrm{b}}$. Assume that the system has reached the steady-state configuration shown in Figure 2, with up-glacier horizontal distance $x$, ice-surface elevation above the origin at the terminus $h_{\mathrm{s}}$, and depth of the overdeepened bed $h_{\mathrm{b}}$ as shown. The surface slope is $\alpha_{\mathrm{s}}=\partial h_{\mathrm{s}} / \partial x$, and the bed slope is $\alpha_{\mathrm{b}}=-\partial h_{\mathrm{b}} / \partial x \equiv \gamma \alpha_{\mathrm{s}}$, where $\gamma$ falls in the range 1.2-1.7 depending on the air-saturation state of the water. Allow the ice thickness to go to zero at the ice front as shown. Let the basal shear stress be the usual $\rho g h \alpha_{\mathrm{s}}$. (Modification for side drag is made by replacing the quantity $\rho g$ by $\rho g S$ wherever the quantity appears in this derivation, in which the shape factor $S$ (Nye, 1952) is 0.5 for a semicircular cross-section and 1 for an infinitely wide glacier, and thicknesses are understood to be measured along the center line for ice flow.) Here $h=h_{\mathrm{s}}+h_{\mathrm{b}}$ as shown in Figure 2 , with $\rho$ the density of ice and $g$ the acceleration of gravity. This yields parabolic profiles with

$$
\begin{aligned}
h_{\mathrm{s}} & =\left[\frac{2 \tau_{\mathrm{b}}}{(1+\gamma) \rho g} x\right]^{1 / 2} \\
h_{\mathrm{b}} & =\gamma h_{\mathrm{s}} .
\end{aligned}
$$

The sediment wedge under the glacier extends up-glacier to $x_{\max }$, with

$$
x_{\max }=\frac{(1+\gamma) \rho g h_{\mathrm{b} \_ \text {max }}^{2}}{2 \gamma^{2} \tau_{\mathrm{b}}} .
$$

Taking $\gamma \approx 1.5$, the extent of the sediment wedge can be calculated from assumed sediment strengths and thicknesses as shown in Figure 3.

For stiff, thin sediments (strength $\tau_{\mathrm{b}}=1 \mathrm{bar}=10^{5} \mathrm{~Pa}$, thickness $h_{\mathrm{b} \_ \text {max }}=10 \mathrm{~m}$ ), the calculated extent is quite small $\left(x_{\max }=5 \mathrm{~m}\right)$, and certainly falls in the complex icemarginal zone where these calculations are not especially meaningful, but the result suggests minimal subglacial sediment. For thick and soft sediment $\left(\tau_{\mathrm{b}}=0.01 \mathrm{bar}=10^{3} \mathrm{~Pa}\right.$; $\left.h_{\mathrm{b} \_\max }=1000 \mathrm{~m}\right), x_{\max }=5000 \mathrm{~km}$ of overrun sediment, sufficiently long that such uniform preglacial conditions are unlikely to have applied, and if they did, a glacier responding to ice-age cycles probably would not have approached steady state; nonetheless, extensive subglacial sediment is suggested. For a wide range of intermediate values, physically plausible yet important lengths of sediment-floored glacier are obtained (e.g. $\tau_{\mathrm{b}}=0.1 \mathrm{bar}=10^{4} \mathrm{~Pa}, h_{\mathrm{b} \_ \text {max }}=$ $100 \mathrm{~m}, x_{\max }=5 \mathrm{~km}$ sediment wedge). 


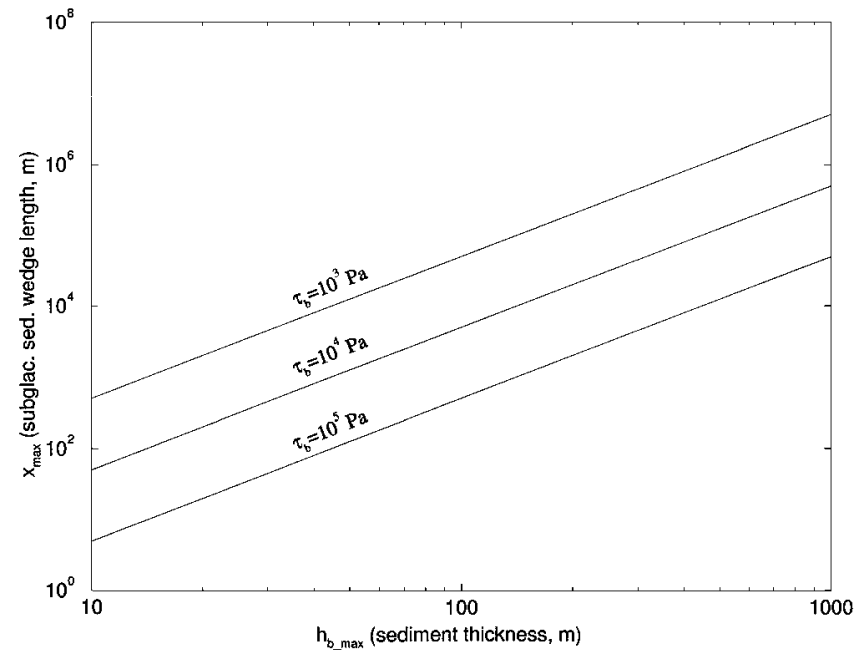

Fig. 3. Lateral extent of over-ridden subglacial sediments as a function of sediment thickness and strength, calculated using perfect-plasticity model.

\section{DISGUSSION}

This simple model suggests a general picture of ice--sediment interactions in terminal regions of advancing or steady glaciers with abundant surface meltwater reaching the glacier bed, in which glaciers over-ride thick proglacial sediments, and supercooling limits the ability of subglacial streams to transport the over-ridden sediments back into the proglacial environment. If this is accurate, several implications follow.

Terminal regions of advancing glaciers are commonly sediment-floored, often for distances that are significant compared to the total glacier length.

Because sediment typically increases the basal velocity (by burying bedrock bumps to smooth the bed for sliding, by allowing additional velocity through sediment deformation, and by creeping into low-pressure water channels and raising basal water pressure (Walder and Fowler, 1994) to speed sliding and bed deformation), terminal regions of advancing glaciers often have high velocity and low ice-air surface slopes, and thus sensitive response to climate changes.

As argued by Nolan and others (1995), dynamics of subglacial and proglacial sediment transport then have major effects on the behavior of glaciers. For example, rapid advance over a sediment wedge will be followed by downcutting through subglacial sediments and associated surface lowering.

Sudden increase in the ability of the non-glacial environment to remove proglacial sediment (say, because a tidewater glacier has recycled a moraine shoal to the edge of the continental shelf, where the steeper continental slope increased loss of sediment from the shoal) can expose the front of the ice to environmental influences that were previously walled off by the sediment, increasing melting or calving and perhaps triggering retreat (e.g. Alley, 1991).

Sediment fluxes from a glacier, hence aggradation of proglacial streams or moraine shoals, often will peakjust after rapid glacial advance has over-ridden sediments to produce slopes shallower than required for supercooling and thus to produce maximum subglacial transport, as documented by Nolan and others (1995). Subsequent overdeepening from sediment transport would reach the supercooling threshold and reduce sediment flux.

Glacier fluctuations favor glacier fluctuations. Subglacial processes produce overdeepenings that act as proglacial sediment traps during ice retreat; subsequent readvance over-rides accumulated sediment, favoring the low-elevation, low-slope ice surface and fast ice flow associated with rapid variations in behavior.

These results lead to two additional points, which have been made by many previous workers.

Sediment-floored as well as bedrock-floored overdeepenings, far from being accidents or curiosities, are fundamental elements of the glacier environment that, through supercooling of subglacial water and related sedimentary and hydrologic processes, exert first-order controls on glacier behavior and geomorphic effects.

To really understand glacier flow, one should know glacial and climatic history as well as physics.

\section{GONCLUSIONS}

Glaciers commonly advance over proglacial sediments that then promote fast glacier flow. We hypothesize that in the presence of abundant meltwater, the ice- ${ }^{-}$sediment contact tends to that angle (slightly greater than $\sim 50 \%$ steeper than and opposed to the surface slope) causing some supercooling of the water. Available data are consistent with this hypothesis. A simple plasticity model based on this hypothesis yields the extent of the over-ridden sediments as a function of the sediment strength and thickness, and may aid in testing the hypothesis.

\section{AGKNOWLEDGEMENTS}

We thank the U.S. National Science Foundation (including grants OPP 0126187 and 9814774) and the U.S. Army Cold Regions Research and Engineering Laboratory for partial funding, G. Denton and the rest of the U.S. National Oceanic and Atmospheric Administration's Abrupt Climate Change Panel, T. Chinn, and A. Meigs for stimulating discussions, D. Mickelson, S. Tulaczyk and an anonymous reviewer for helpful suggestions, and our colleagues at Matanuska Glacier for long-standing collaborations.

\section{REFERENCES}

Alley, R. B. 1989. Water-pressure coupling of sliding and bed deformation: I. Water system. f. Glaciol., 35(119), 108-118.

Alley, R. B. 1991. Sedimentary processes may cause fluctuations of tidewater glaciers. Ann. Glaciol., 15, 119-124.

Alley, R. B. 1997. Water, sediment and tidewater glaciers; simplistic review and weakly constrained speculations. Byrd Polar Res. Cent. Rep. 15, 51-55.

Alley, R. B., K. M. Cuffey, E. B. Evenson, J. C. Strasser, D. E. Lawson and G. J. Larson. 1997. How glaciers entrain and transport basal sediment: physical constraints. Quat. Sci. Rev., 16(9), 1017-1038.

Alley, R. B., D. E. Lawson, E. B. Evenson, J. C. Strasser and G. J. Larson. 1998. Glaciohydraulic supercooling: a freeze-on mechanism to create stratified, debris-rich basal ice. II. Theory. F. Glaciol., 44(148), 563-569.

Alley, R. B., J. C. Strasser, D. E. Lawson, E. B. Evenson and G. J. Larson. 1999. Some glaciological and geological implications of basal-ice accretion in an overdeepening. In Mickelson, D. M. and J.W. Attig, eds. Glacial processes: past and present. Boulder, CO, Geological Society of America, 1-9. (Special Paper 337.)

Arcone, S. A., D. E. Lawson and A. J. Delaney. 1995. Short-pulse radar wave- 
let recovery and resolution of dielectric contrasts within englacial and basal ice of Matanuska Glacier, Alaska, U.S.A. f. Glaciol., 41(137), 68-86.

Arcone, S. A., D. E. Lawson, M. Moran and A. J. Delaney. 2000. 12-100$\mathrm{MHz}$ profiles of ice depth and stratigraphy of three temperate glaciers. In Noon, D., G. F. Stickley and D. Longstaff, eds. GPR 2000, Eighth International Conference on Ground Penetrating Radar, 23-26 May 2000, Gold Coast, Australia. Bellingham, WA, International Society of Photo-optical Instrumentation Engineers, 377-382. (SPIE Proceedings 4084.)

Barnes, D. F. 1987. Gravity anomaly at a Pleistocene lake bed in NW Alaska interpreted by analogy with Greenland's Lake Taserssauq and its floating ice tongue. 7. Geophys. Res., 92(B9), 8976-8984.

Bell, M. and E. P. Laine. 1985. Erosion of the Laurentide region of North America by glacial and glaciofluvial processes. Quat. Res., 23(2), 154-174.

Bennett, M. R. 2001. The morphology, structural evolution and significance of push moraines. Earth Sci. Rev., 53(3-4), 197-236.

Björnsson, H. 1996. Scales and rates of glacial sediment removal: a $20 \mathrm{~km}$ long, $300 \mathrm{~m}$ deep trench created beneath Breiðamerkurjökull during the Little Ice Age. Ann. Glaciol., 22, 141-146.

Blankenship, D. D., C. R. Bentley, S. T. Rooney and R. B. Alley. 1987. Till beneath Ice Stream B. 1. Properties derived from seismic travel times. 7. Geophys. Res., 92(B9), 8903-8911.

Boulton, G. S., K. E. Dobbie and S. Zatsepin. 2001. Sediment deformation beneath glaciers and its coupling to the subglacial hydraulic system. Quat. Int., 86, 3-28.

Brocklehurst, S. H. and K. X. Whipple. 2002. Glacial erosion and relief production in the eastern Sierra Nevada, California. Geomorphology, 42(1-2), $1-24$

Burbank, D. W. and 6 others. 1996. Bedrock incision, rock uplift and threshold hillslopes in the north-western Himalayas. Nature, 379 (6565), 505-510.

Carter, L., H. L. Neil and I. N. McCave. 2000. Glacial to interglacial changes in non-carbonate and carbonate accumulation in the SW Pacific Ocean, New Zealand. Palaeogeogr., Palaeoclimatol., Palaeoecol., 162(3-4), 333-356.

Chinn, T. J. 1996. New Zealand glacier responses to climate change of the past century. N.Z. F. Geol. Geophys., 39(3), 415-428.

Clark, P. U., R. B. Alley and D. Pollard. 1999. Northern Hemisphere icesheet influences on global climate change. Science, 286(5442), 1104-1111.

Cuffey, K. and R. B. Alley. 1996. Is erosion by deforming subglacial sediments significant? (Toward till continuity.) Ann. Glaciol., 22, 17-24.

Cuffey, K. M., H. Conway, B. Hallet, A. M. Gades and C. F. Raymond 1999. Interfacial water in polar glaciers and glacier sliding at $-17^{\circ} \mathrm{C}$. Geophys. Res. Lett., 26(6), 751-754.

Ensminger, S. L., E. B. Evenson, R. B. Alley, G. J. Larson, D. E. Lawson and J. C. Strasser. 1999. Example of the dependence of ice motion on subglacial drainage system evolution: Matanuska Glacier, Alaska, United States. In Mickelson, D. M. and J. W. Attig, eds. Glacial processes: past and present. Boulder, CO, Geological Society of America, 11-22. (Special Paper 337.)

Ensminger, S. L., R. B. Alley, E. B. Evenson, D. E. Lawson and G. J. Larson. 2001. Basal-crevasse-fill origin of laminated debris bands at Matanuska Glacier, Alaska, U.S.A. 7. Glaciol., 47(158), 412-422.

Evenson, E. B. and 6 others. 1999. Field evidence for the recognition of glaciohydraulic supercooling. In Mickelson, D. M. and J.W. Attig, eds. Glacial processes: past and present. Boulder, CO, Geological Society of America, 23-35. (Special Paper 337.)

Hallet, B. 1996. Glacial quarrying: a simple theoretical model. Ann. Glaciol., $22,1-8$.

Hallet, B., L. E. Hunter and J. Bogen. 1996. Rates of erosion and sediment evacuation by glaciers: a review of field data and their implications. Global Planet. Change, 12(1-4), 213-235.

Hooke, R. LeB. 1991. Positive feedbacks associated with erosion of glacia cirques and overdeepenings. Geol. Soc. Am. Bull., 103(8), 1104-1108.

Hooke, R. LeB. and V. A. Pohjola. 1994. Hydrology of a segment of a glacier situated in an overdeepening, Storglaciären, Sweden. 7. Glaciol., 40(134), 140-148.

Humphrey, N., B. Kamb, M. Fahnestock and H. Engelhardt. 1993. Characteristics of the bed of the lower Columbia Glacier, Alaska. 7. Geophys. Res., $98(\mathrm{~B} 1), 837-846$.

Hunter, L. E., R. D. Powell and D. E. Lawson. 1996a. Flux of debris transported by ice at three Alaskan tidewater glaciers. F. Glaciol., 42(140), 123-135.

Hunter, L. E., R. D. Powell and D. E. Lawson. 1996b. Morainal-bank sediment budgets and their influence on the stability of tidewater termini of valley glaciers entering Glacier Bay, Alaska, U.S.A. Ann. Glaciol., 22, 211-216.
Iverson, N. R. 1991. Potential effects of subglacial water-pressure fluctuations on quarrying. F. Glaciol., 37(125), 27-36.

Kamb, B. and K. A. Echelmeyer. 1986. Stress-gradient coupling in glacier flow: I. Longitudinal averaging of the influence of ice thickness and surface slope. 7. Glaciol., 32(111), 267-284.

Koppes, M. N. and B. Hallet. 2002. Influence of rapid glacial retreat on the rate of erosion by tidewater glaciers. Geology, 30(1), 47-50.

Larson, G. and R. Schaetzl. 2001. Origin and evolution of the Great Lakes. 7. Great Lakes Res., 27(4), 518-546.

Lawson, D. E. 1979. Sedimentological analysis of the western terminus region of the Matanuska Glacier, Alaska. CRREL Rep. 79-9.

Lawson, D. E. 1986. Observations on hydraulic and thermal conditions at the bed of Matanuska Glacier, Alaska. In Hydraulic Effects at the Glacier Bed and Related Phenomena, International Workshop, 16-19 September 1985 Interlaken, Switzerland. Zürich, ETH. Versuchsanstalt für Wasserbau, Hydrologie und Glaziologie, 69-71. (Mitteilungen 90.)

Lawson, D. E. 1993. Glaciohydrologic and glaciohydraulic effects on runoff and sediment yield in glacierized basins. CRREL Monogr. 93-02.

Lawson, D. E., J. C. Strasser, E. B. Evenson, R. B. Alley, G. J. Larson and S. A. Arcone. 1998b. Glaciohydraulic supercooling: a freeze-on mechanism to create stratified, debris-rich basal ice. I. Field evidence. F. Glaciol., 44(148), 547-562.

Meier, M. F. and A. Post. 1987. Fast tidewater glaciers. 7. Geophys. Res., 92(B9), 9051-9058.

Meigs, A. and J. Sauber. 2000. Southern Alaska as an example of the longterm consequences of mountain building under the influence of glaciers. Quat. Sci. Rev., 19(14-15), 1543-1562.

Mickelson, D. M., L. Clayton, D. S. Fullerton and H.W. Borns, Jr. 1983. The Late Wisconsin glacial record of the Laurentide ice sheet in the United States. In Wright, H. E., Jr, ed. Late-Quaternary environments of the United States. Volume 1. Minneapolis, MN, University of Minnesota Press, 3-37.

Nolan, M., R. J. Motyka, K. Echelmeyer and D. C. Trabant. 1995. Ice-thickness measurements of Taku Glacier, Alaska, U.S.A., and their relevance to its recent behavior. F. Glaciol., 41(139), 541-553. (Erratum: 42(141), 1996, p. 400.

Nye, J. F. 1951. The flow of glaciers and ice-sheets as a problem in plasticity Proc. R. Soc. London, Ser. A, 207(1091), 554-572.

Nye, J. F. 1952. The mechanics of glacier flow. F. Glaciol., 2(12), 82-93.

Paterson, W. S. B. 1994. The physics of glaciers. Third edition. Oxford, etc., Elsevier.

Pearce, J.T. and 6 others. 2003. Bedload component of glacially discharged sediment: insights from the Matanuska Glacier, Alaska. Geology, 31(1), 7-10.

Powell, R. D. 1990. Glacimarine processes at grounding-line fans and their growth to ice-contact deltas. In Dowdeswell, J. A. and J. D. Scourse, eds Glacimarine environments: processes and sediments. London, Geological Society, 53-73. (Special Publication 53.)

Roberts, M. J. and 7 others. 2002. Glaciohydraulic supercooling in Iceland. Geology, $30(5), 439-442$.

Röthlisberger, H. and H. Lang. 1987. Glacial hydrology. In Gurnell, A. M and M. J. Clark, eds. Glacio-fluvial sediment transfer: an alpine perspective. Chichester, etc., John Wiley and Sons, 207-284.

Spedding, N. and D. J. A. Evans. In press. Sediments and landforms at Kvíarjökull, south-east Iceland: a reappraisal of the glaciated valley landsystem. Sediment. Geol.

ten Brink, U. S., R. I. Hackney, S. Bannister, T. A. Stern and Y. Makovsky. 1997. Uplift of the Transantarctic Mountains and the bedrock beneath the East Antarctic ice sheet. 7. Geophys. Res., 102(B12), 27,603-27,621.

Tulaczyk, S. M., B. Kamb and H. F. Engelhardt. 2000. Basal mechanics of Ice Stream B, West Antarctica. I. Till mechanics. F. Geophys. Res., 105(B1) 463-481.

Tulaczyk, S. M., R. P. Scherer and C. D. Clark. 2001. A ploughing model for the origin of weak tills beneath ice streams: a qualitative treatment Quat. Int., 86(1), 59-70.

Walder, J. S. 1982. Stability of sheet flow of water beneath temperate glaciers and implications for glacier surging. 7. Glaciol., 28(99), 273-293.

Walder, J. S. and A. Fowler. 1994. Channelized subglacial drainage over a deformable bed. 7. Glaciol., 40(134), 3-15

Warren, C. R. and M. P. Kirkbride. 1998. Temperature and bathymetry of ice-contact lakes in Mount Cook National Park, New Zealand. N.Z. J Geol. Geophys., 41 (2), 133-143.

Weertman, J. 1964. The theory of glacier sliding. F. Glaciol., 5(39), 287-303. 